\title{
EFEKTIFITAS EKSTRAK DAUN PATIKAN KEBO (Euphorbia hirta L) SEBAGAI OVISIDA TERHADAP NYAMUK DEMAM BERDARAH DENGUE (Aedes aegypti)
}

\author{
Gres Maretta $^{1 *}$, Eko Kuswanto ${ }^{2}$, Nur Intan Septikayani ${ }^{3}$ \\ ${ }^{1}$ Institut Teknologi Sumatra, Lampung \\ ${ }^{2,3}$ Universitas Islam Negeri Raden Intan Lampung \\ "Email: gresmaretta2@gmail.com
}

Received: April 29 $9^{\text {th }}, 2019$. Accepted: June $26^{\text {th }}, 2019$. Published: April $29^{\text {th }}, 2019$

\begin{abstract}
Abstrak
One of the dangerous diseases that can cause a high mortality rate is the dengue virus that is transmitted to humans through female mosquito bites (Aedes aegypti). To reduce the use of synthetic pesticides, it is necessary to use vegetable pesticides, namely patikan kebo leaf extract (Euphorbia hirta L) because inside this leaf there is a content of secondary metabolites which can act as oviside. The purpose of this study was to determine whether patikan kebo leaf extract (Eupborbia hirta L.) can be used as an oviside against mosquito eggs in Dengue Hemorrhagic Fever (Aedes aegypti), and to determine the most effective concentration of patikan kebo leaf extract (Eupborbia hirta L.) as mosquito oviside Dengue Hemorrhagic Fever (Aedes aegypti). This study uses a completely randomized design method (CRD) that is there are four repetitions with six treatments namely negative control (Aquades) and positive control (Tween 80) and concentrations of 0.125\%, 0.25\%, $0.5 \%$ and $1 \%$. Patikan kebo leaf extract (Euphorbia hirta L) can be used as ovisida against eggs of Dengue Hemorrhagic Fever (Aedes aegypti) from a concentration of 0.125\% - 1\%. The higher the concentration of patikan kebo leaf extract (Euphorbia hirta L) is used the more eggs not hatch.
\end{abstract}

Keywords: Dengue Hemorrhagic fever, Mosquito Eggs (Aedes aegypit), RAL, Tween 80, Patikan Kebo (Euphorbia hirta L).

\begin{abstract}
Abstrak
Salah satu penyakit yang berbahaya dan dapat menyebabkan angka kematian tinggi yaitu virus Dengue yang di tularkan kepada manusia melalui gigitan nyamuk Demam Berdarah Dengue (Aedes aegypti) betina. Untuk mengurangi penggunaan pestisida sintetik maka diperlukan penggunaan pestisida nabati yaitu ekstrak daun patikan kebo (Euphorbia hirta L.) karena di dalam daun ini terdapat kandungan senyawa metabolit sekunder yang dapat berperan sebagai ovisida. Tujuan penelitian ini adalah untuk mengetahui apakah ekstrak daun patikan kebo (Eupborbia hirta L.) dapat digunakan sebagai ovisida terhadap telur nyamuk Demam Berdarah Dengue (Aedes aegypti), dan mengetahui konsentrasi yang paling efektif dari ekstrak daun patikan kebo (Eupborbia hirta L.) sebagai ovisida nyamuk Demam Berdarah Dengue (Aedes aegypti). Penelitian ini dengan menggunakan metode Rancangan Acak lengkap (RAL) yaitu terdapat empat pengulangan dengan enam perlakuan yaitu kontrol negatif (Aquades) dan kontrol positif (Tween 80) serta konsentrasi $0,125 \%, 0,25 \%, 0,5 \%$ dan $1 \%$. Hasil penelitian menunjukkan bahwa, ekstrak daun patikan kebo (Euphorbia hirta L) dapat digunakan sebagai ovisida terhadap telur nyamuk Demam Berdarah Dengue (Aedes aegypti) dari konsentrasi 0,125\% - 1\%. Semakin tinggi konsentrasi ekstrak daun patikan kebo (Euphorbia hirta $L$ ) yang digunakan maka semakin banyak telur yang tidak menetas.
\end{abstract}

Kata Kunci: Demam Berdarah Dengue, Patikan Kebo (Euphorbia hirta L), RAL, Telur Nyamuk (Aedes aegypit), Tween 80.

\section{PENDAHULUAN}

Demam Berdarah Dengue (DBD) adalah salah satu penyakit yang berbahaya bagi kesehatan manusia. DBD ini disebabkan oleh virus dengue yang ditularkan kepada manusia melalui gigitan nyamuk betina spesies Aedes aegepty (Data \& RI, 2010). Masyarakat dan 
pemerintah telah melakukan berbagai pengendalian untuk mencegah peningkatan penyebaran penyakit DBD, namun penyakit DBD semakin tahun terus meningkat. Pengendalian vektor DBD yang banyak dilakukan oleh masyarakat dan pemerintah yaitu Metode kimia dengan memanfaatkan insektisida buatan pabrik yang menimbulkan resistensi terhadap nyamuk, selain itu bahan kimia yang terkandung dalam insektisida dapat menyebabkan kerusakan lingkungan (Iftita, 2016). Faktor lain yang mempengaruhi tidak berhasilnya pengendalian yang dilakukan pemerintah karena pemberantasan nyamuk hanya berfokus pada stadium dewasa saja tanpa membasmi stadium yaitu telur dan larva, Stadium telur merupakan stadium yang sangat rentan terhadap insektisida, sehingga apabila dibasmi pada stadium telur akan lebih menguntungkan. Namun, masih sedikit penelitian yang dilakukan untuk membasmi telur nyamuk, sehingga perlu dilakukan usaha pemutusan mata rantai penularan penyakit dengan menggunakan insektisida pada telur nyamuk. Insektisida yang digunakan dengan memanfaatkan ekstrak tumbuhan sebagai insektisida alami yang lebih aman dan ramah lingkungan karena memiliki residu yang pendek dan efek samping yang jauh lebih kecil bagi manusia.

Patikan kebo (Euphorbia hirta L) merupakan Tanaman herba yang dapat hidup di daerah beriklim tropis, dan hidup di permukaan tanah dengan keadaan tanah yang tidak terlalu lembab. Patikan kebo (Euphorbia hirta L) merupakan salah satu jenistanaman yang digunakan sebagai obat dan terdapat banyak di Indonesia dan tanaman ini hidup terpencar antara satu dengan yang lainnya. Merupakan herba yang berukuran kecil dan bergetah. Salah satu tumbuhan yang dapat dimanfaatkan sebagai obat herbal yaitu patikan kebo dengan nama latin (Euphorbia hirta L.) Berdasarkan penelitian yang telah dilakukan oleh para ahli tumbuhan Patikan kebo (Eupborbia hirta L.) merupakan salah satu rumput yang mengandung senyawa-senyawa kimia dan dapat bersifat sebagai antiseptik, anti-inflamasi, antifungal dan anti bakterial. Kandungan senyawa kimia tersebut seperti flavonoid, terpenoid selain itu terdapat juga kandungan senyawa aktif lainnya seperti alkaloid dan polifenol (Karim, Jura, \& Sabang, 2015).

Senyawa flavonoid, terpenoid dan alkaloid merupakan senyawa yang memiliki kemampuan untuk menghambat bahkan merusak membran telur sehingga senyawa flavonoid, terpenoid dan alkaloid pada tanaman patikan kebo (Euphorbia hirta L.) kemungkinan besar bisa digunakan sebagai ovisida. Hal ini sama dengan Penelitian yang dilakukan oleh Jeyasankar yang menggunakan ekstrak dari tumbuhan Andrographis paniculataatau sambiloto sebagai ovisida nyamuk golongan Dipteramemberikan kesimpulan bahwa pada konsentrasi paling tinggi yaitu $250 \mathrm{ppm}$ ekstrak dapat membunuh telur nyamuk Aedes aegypti, An. Stephensi dan Culex sp. dan juga menggagalkan penetasan telur menjadi larva, hal tersebut dikarenakan adanya kandungan fitokimia yaitu glycosida dan flavonoid yang dapat menghambat perkembangbiakkan telur (Raveen et al., 2017).

Berdasarkan hal tersebut terdapat perbedaan, bahwa penelitian ini tentang efektivitas Ekstrak Daun Patikan Kebo (Euphorbia hirta L) sebagai ovisida terhadap nyamuk DBD (Aedes aegypti) dengan tujuan Untuk mengetahui apakah ekstrak daun patikan kebo (Eupborbia hirta L.) dapat digunakan sebagi ovisida terhadap telur nyamuk DBD (Aedes aegypti), dan untuk mengetahui konsentrasi yang paling efektif dari ekstrak daun patikan kebo (Eupborbia hirta L.) sebagai ovisida nyamuk DBD (Aedes aegypti). Dalam penelitian ini terdapat hipotesis yaitu :

$\mathrm{H}_{0} \quad$ : Ekstrak daun patikan kebo (Euphorbia hirta L.) tidak berpengaruh sebagai ovisida terhadap telur nyamuk DBD (Aedes aegypti) 
$\mathrm{H}_{1} \quad$ : Ekstrak daun patikan kebo (Euphorbia hirta L.) berpengaruh sebagai ovisida terhadap telur nyamuk DBD (Aedes aegypti)

Hipotesis $\mathrm{H} 0$ ditolak pada taraf nyata $\alpha$ bila $F_{\text {hitung }}>F_{\text {tabel }}$.

\section{METODE PENELITIAN}

Penelitian ini merupakan penelitian eksperimental, populasi dalam penelitian ini adalah telur nyamuk DBD (Aedes aegypti). Sampel uji yang diperlukan dalam setiap kali perlakuan berjumlah 25 telur nyamuk DBD (Aedes aegypti) dan terdapat empat kali pengulangan sehingga jumlah sampel telur DBD (Aedes aegypti) yang digunakan dalam penelitian ini adalah 600 telur.

Daun patikan kebo (Euphorbia hirta L.) yang diperlukan dalam pembuatan ekstrak yaitu memiliki berat 3,5 Kg dalam keadaan basah, kemudian daun yang sudah di peroleh dibersihkan, dan menjemurnya sampai kering pada suhu ruang selama 24 jam dan dijemur dibawah sinar matahari, kemudian diblender. Setelah diblender diperoleh serbuk daun patikan kebo (Euphorbia hirta L.) diekstraksi dengan cara maserasi yaitu merendam dengan ethanol 96\% sebanyak 2 liter selama 24 jam (Mitarlis, Ismono, \& Tukiran, 2011). Setelah dimaserasi kemudian disaring larutan tersebut kemudian diambil sarinya dan melakukan evaporasi pada suhu $50^{\circ}-60^{\circ} \mathrm{C}$, sehingga diperoleh hasil akhirnya berupa ekstrak daun patikan kebo (Euphorbia hirta L.) 100\%.

Uji fitokimia dilakukan dengan cara memasukkan sampel ekstrak daun patikan kebo (Euphorbia hirta L) ke dalam tabung reaksi sebanyak 0,5 ml kemudian ditambahkan dengan aquades sebanyak $2 \mathrm{ml}$, setelah itu kocok selama kurang lebih 1 menit, terdapatnya senyawa saponin dalam ekstrak ditandai dengan adanya buih atau busa.

Memasukkan ekstrak daun patikan kebo (Euphorbia hirta L) sebanyak $1 \mathrm{ml}$ ke dalam tabung reaksi, kemudian ditambah dengan satu tetes $\mathrm{FeCl}_{3}$ terdapatnya senyawa tanin di tandai dengan perubahan warna pada ekstrak yaitu menjadi hijau kehitaman.

Memasukkan ekstrak daun patikan kebo (Euphorbia hirta L) ke dalam tabung reaksi sebanyak 0,5 ml kemudian ditambah dengan asam asetat glacial dan $\mathrm{H}_{2} \mathrm{SO}_{4}$, perubahan warna biru pada ekstrak menandakan bahwa ekstrak mengandung senyawa steroid.

Memasukkan ekstrak daun patikan kebo (Euphorbia hirta L) ke dalam tabung reaksi sebanyak $5 \mathrm{ml}$ kemudian ditambah dengan serbuk $\mathrm{Mg}$ dan menambahkan $\mathrm{HCl}$ pekat, terjadinya perubahan warna kuning, merah atau jingga menunjukkan ekstrak mengandung senyawa flavonoid.

Memasukkan ekstrak daun patikan kebo (Euphorbia hirta L) ke dalam tabung reaksi kemudian menambahkan kloroflom dan menambahkan pereaksi mayer $\left(\mathrm{HgCl}_{2}+\right.$ kalium iodida), terbentuknya warna putih kekuningan serta terdapat endapan merah jingga menunjukkan bahwa ekstrak mengandung senyawa alkaloid.

Memasukkan ekstrak daun patikan kebo (Euphorbia hirta L) ke dalam tabung reaksi kemudian menambahkan asam asam asetat glacial dan $\mathrm{H}_{2} \mathrm{SO}_{4}$ perubahan warna merah pada ekstrak menunjukkan bahwa ekstrak mengandung senyawa terpenoid (Karim et al., 2015).

Uji efektivitas dalam penelitian ini yaitu menggunakan ekstrak daun patikan kebo (Euphorbia hirta L.) dengan konsentrasi 1\%, 0,5\%, 0,25\%, 0,125\%, sebelum melakukan uji efektivitas diperlukan pengenceran ekstrak dengan menggunakan aquades di dalam beaker 
glass dan aquades yang dibutuhkan disesuaikan dengan konsentrasi yang digunakan, setelah proses pengenceran selesai kemudian memasukan telur nyamuk DBD (Aedes aegypti) yang telah dihitung dengan menggunakan mikroskop, telur nyamuk yang dimasukkan ke dalam beaker glass sebanyak 25 butir setiap perlakuan, dan untuk perlakuan kontrol negatif dengan menggunakan aquades (Cheah, Tay, Chan, \& Jaal, 2013a). Masing-masing perlakuan dilakukan pengamatan 6 jam sekali selama 72 jam, pengamatan dilakukan dengan melihat telur yang telah menetas menjadi larva.

Total telur tidak menetas $\quad$ : Jumlah dari seluruh telur di empat pengulangan

Rata-rata telur tidak menetas $: \frac{\text { Jumlah telur tidak menetas }}{\text { Banyaknya pengulangan }}$

$\%$ Kematian telur

$$
: \frac{\text { Jumlah telur tidak menetas }}{\text { Total keseluruhan dalam pengulangan }} \times 100 \%
$$

(Raveen et al., 2017)

Penelitian ini juga melakukan pengukuran $\mathrm{pH}$ dan suhu pada media uji efektivitas ekstrak yang di gunakan untuk perlakuan telur nyamuk DBD (Aedes aegypti), pengukuran $\mathrm{pH}$ dan suhu dilakukan setiap 6 jam sekali, pengukuran $\mathrm{pH}$ dan suhu ini di lakukan dengan. menggunakan $\mathrm{pH}$ meter, $\mathrm{pH}$ yang ideal untuk penetasan telur nyamuk yaitu berkisar 6-8. Dan suhu yang optimum untuk penetasan telur yaitu berkisar $27^{\circ} \mathrm{C}-32^{\circ} \mathrm{C}$ (Mayangsari, Sidharti, \& Kurniawan, 2015).

Berdasarkan hasil percobaan yang telah dilakukan maka untuk mengetahui efektifitas ekstrak daun patikan kebo (Euphorbia hirta L.) yaitu dilakukan analisis data jika data yang diperoleh normal maka dilakukan uji ANOVA satu jalur (one way ANOVA), kemudian untuk mengetahui perlakuan mana yang paling efektif dari setiap perlakuan dilanjutkan dengan uji BNT atau LSD pada taraf 0,05.

\section{HASIL PENELITIAN DAN PEMBAHASAN}

Berdasarkan uji fitokimia yang telah dilakukan pada daun Patikan Kebo (Euphorbia hirta L) mengandung senyawa metabolit disajikan pada Tabel 1 sebagai berikut:

Tabel 1. Uji Fitokimia Ekstrak Daun Patikan Kebo (Euphorbia hirta L)

\begin{tabular}{cclc}
\hline $\begin{array}{c}\text { Senyawa } \\
\text { Metabolit }\end{array}$ & Pereaksi & \multicolumn{1}{c}{ Hasil Pengamatan } & Keterangan \\
\hline Saponin & Aquades & Terdapat busa \\
Tanin & $\mathrm{FeCl}_{3}$ & Warna larutan hitam kebiruan & + \\
Steroid & Asam asetat glacial + & Sample tidak berubah menjadi & - \\
& $\mathrm{H}_{2} \mathrm{SO}_{4}$ & warna biru & \\
Flavonoid & $\mathrm{Mg}+\mathrm{HCl}$ & Warna larutan merah/ kuning & + \\
Alkaloid & Mayer & Warna tidak berubah menjadi & - \\
& & putih kecoklatan & + \\
Terpenoid & Asam asetat glacial + & Warna sample berubah menjadi & + \\
& $\mathrm{H}_{2} \mathrm{SO}_{4}$ & merah atau kuning & \\
\hline
\end{tabular}

Keterangan : 
(+) : terdapat senyawa metabolit pada ekstrak

$(-)$ : tidak terdapat senyawa metabolit pada ekstrak.

Setelah ekstrak yang dibuat jadi maka dilakukan uji efektivitas Ekstrak daun patikan kebo (Euphorbia hirta L) sebagai ovisida terhadap telur nyamuk DBD (Aedes aegypti) selama 72 jam, tetapi diamati setiap 6 jam sekali, berikut data yang diperoleh dalam penelitian yang telah dilakukan:

Tabel 2 Pengamatan Telur Nyamuk Demam Berdarah Dengue (Aedes Aegypti) pada Jam Ke-72

\begin{tabular}{|c|c|c|c|c|c|c|c|c|}
\hline \multirow[t]{2}{*}{ Konsentrasi } & \multirow{2}{*}{$\begin{array}{l}\text { Jumlah } \\
\text { Telur }\end{array}$} & \multicolumn{4}{|c|}{$\begin{array}{c}\text { Jumlah Telur yang tidak } \\
\text { Menetas }\end{array}$} & \multirow[t]{2}{*}{ Total } & \multirow{2}{*}{$\begin{array}{c}\text { Rerata } \\
\text { Telur } \\
\text { Tidak } \\
\text { Menetas }\end{array}$} & \multirow{2}{*}{ 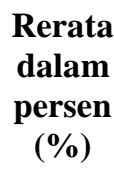 } \\
\hline & & 1 & 2 & 3 & 4 & & & \\
\hline $\begin{array}{l}\text { Kontrol - } \\
\text { (aquades) }\end{array}$ & 100 & 3 & 0 & 2 & 1 & 6 & 1.5 & $6 \%$ \\
\hline $\begin{array}{l}\text { Kontrol + } \\
\text { (Tween) }\end{array}$ & 100 & 3 & 4 & 4 & 5 & 16 & 4 & $16 \%$ \\
\hline $0,125 \%$ & 100 & 7 & 6 & 8 & 4 & 25 & 6,25 & $25 \%$ \\
\hline $0,25 \%$ & 100 & 9 & 8 & 7 & 5 & 29 & 7,25 & $29 \%$ \\
\hline $0,5 \%$ & 100 & 9 & 9 & 8 & 6 & 32 & 8 & $32 \%$ \\
\hline $1 \%$ & 100 & 9 & 7 & 9 & 8 & 33 & 8,25 & $33 \%$ \\
\hline
\end{tabular}

Berdasarkan tabel hasil penelitian pada jam ke 72 telur yang tidak menetas pada perlakuan kontrol negatif $0 \%$ rata-rata telur yang tidak menetas 1,5 sedangkan pada perlakuan kontrol positif rata-rata telur yang tidak menetas 4 , pada konsentrasi $0,125 \%$ rata-rata telur yang tidak menetas 6,25 , pada konsentrasi $0,25 \%$ rata-rata telur yang tidak menetas 7,25 pada konsentrasi $0,5 \%$ rata-rata telur yang tidak menetas 8 , sedangkan pada konsentrasi $1 \%$ rata-rata telur yang tidak menetas 8,25 .

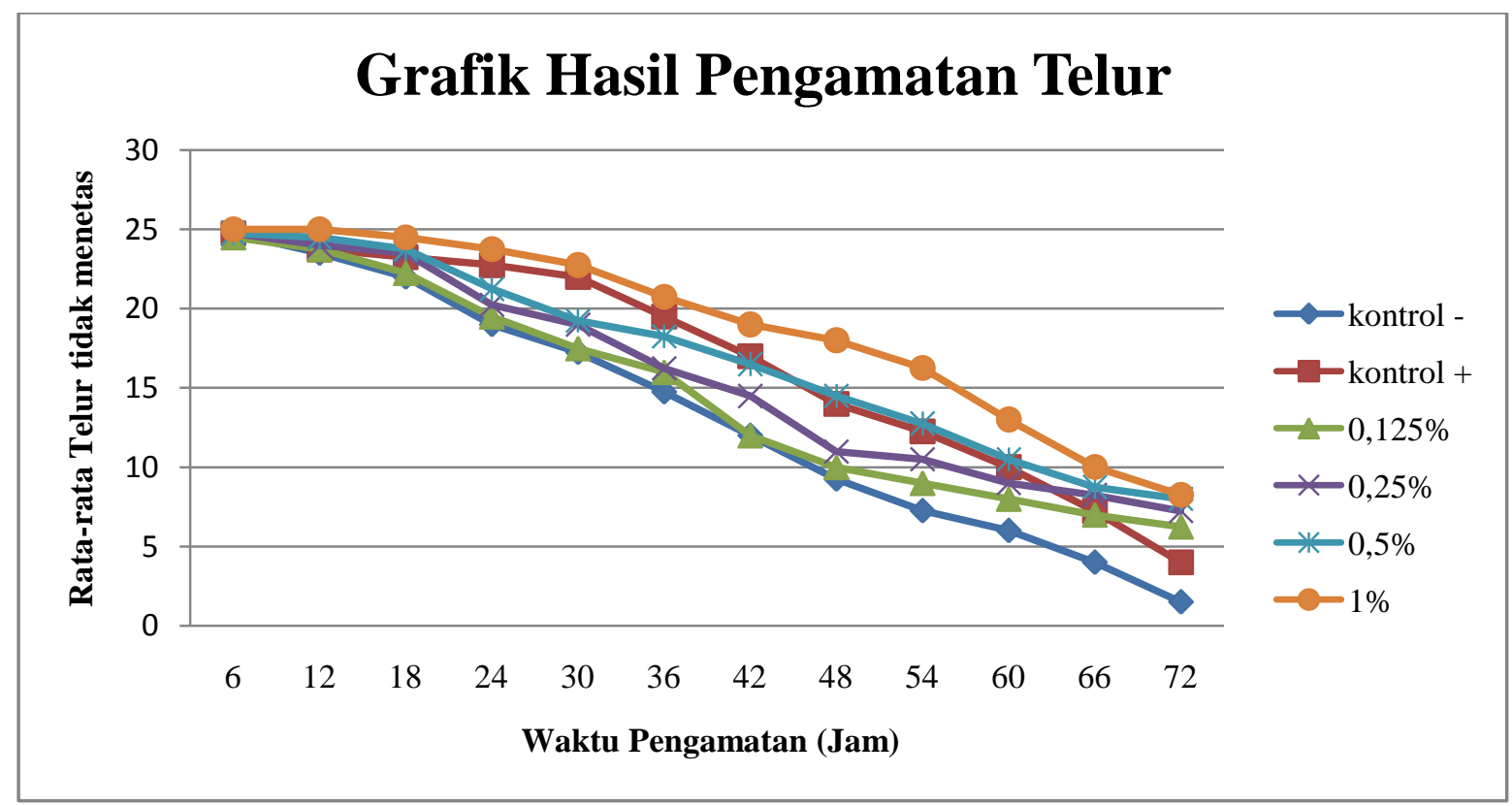

Gambar 1. Grafik Hasil Pengamatan 
Berdasarkan gambar 1 menunjukkan bahwa hasil yang diperoleh dari pengamatan 6 jam pertama hingga jam ke 72 mengalami penurunan baik pada kontrol negatif, kontrol positif, perlakuan $0,125 \%, 0,25 \%, 0,5 \%$, dan $1 \%$. Penurunan pada grafik menunjukkan bahwa setiap 6 jam pengamtan terdapat telur yang menetas.

Tabel 3. Pengukuran Suhu Pada Jam Ke- 72

\begin{tabular}{|c|c|c|c|c|c|c|}
\hline \multirow{2}{*}{ Konsentrasi } & \multirow{2}{*}{$\begin{array}{l}\text { Suhu normal } \\
\text { biakan telur }\end{array}$} & \multicolumn{4}{|c|}{ Suhu Pada Jam Ke-72(pengulangan) } & \multirow[t]{2}{*}{ Rata-rata } \\
\hline & & 1 & 2 & 3 & 4 & \\
\hline Kontrol-(aquades) & \multirow{6}{*}{$27-32^{\circ} \mathrm{C}$} & $28,1^{\circ} \mathrm{C}$ & $28,1^{\circ} \mathrm{C}$ & $28,1^{\circ} \mathrm{C}$ & $28,1^{\circ} \mathrm{C}$ & $28,1^{\circ} \mathrm{C}$ \\
\hline Kontrol +(Tween) & & $28,1^{\circ} \mathrm{C}$ & $28,1^{\circ} \mathrm{C}$ & $28,1^{\circ} \mathrm{C}$ & $28,1^{\circ} \mathrm{C}$ & $28,1^{\circ} \mathrm{C}$ \\
\hline $0,125 \%$ & & $28,1^{\circ} \mathrm{C}$ & $28,1^{\circ} \mathrm{C}$ & $28,1^{\circ} \mathrm{C}$ & $28,1^{\circ} \mathrm{C}$ & $28,1^{\circ} \mathrm{C}$ \\
\hline $0,25 \%$ & & $28,1^{\circ} \mathrm{C}$ & $28,1^{\circ} \mathrm{C}$ & $28,1^{\circ} \mathrm{C}$ & $28,1^{\circ} \mathrm{C}$ & $28,1^{\circ} \mathrm{C}$ \\
\hline $0,5 \%$ & & $28,1^{\circ} \mathrm{C}$ & $28,1^{\circ} \mathrm{C}$ & $28,1^{\circ} \mathrm{C}$ & $28,1^{\circ} \mathrm{C}$ & $28,1^{\circ} \mathrm{C}$ \\
\hline $1 \%$ & & $28,1^{\circ} \mathrm{C}$ & $28,1^{\circ} \mathrm{C}$ & $28,1^{\circ} \mathrm{C}$ & $28,1^{\circ} \mathrm{C}$ & $28,1^{\circ} \mathrm{C}$ \\
\hline
\end{tabular}

Berdasarkan pengkuran suhu media yang telah dilakukan pada jam ke-72 dari setiap perlakuan yaitu kontrol negatif, kontrol positif dan konsentrasi 1\%, 0,5\%. 0,25\%. 0,125\%, hasil yang diperoleh sama dengan rata-rata $28,1^{\circ} \mathrm{C}$.

Tabel 4. Pengukuran pH Pada Jam Ke-72

\begin{tabular}{|c|c|c|c|c|c|c|}
\hline \multirow{2}{*}{ Konsentrasi } & \multirow{2}{*}{$\begin{array}{l}\mathrm{pH} \text { normal } \\
\text { biakan telur }\end{array}$} & \multicolumn{4}{|c|}{ pH Pada Jam Ke-72 } & \multirow[t]{2}{*}{ Rata-rata } \\
\hline & & 1 & 2 & 3 & 4 & \\
\hline Kontrol - (aquades) & & 7 & 7 & 7 & 7 & 7 \\
\hline Kontrol+ (Tween) & & 6,28 & 6,28 & 6,28 & 6,28 & 6,28 \\
\hline $0,125 \%$ & $6-8$ & 6,16 & 6,16 & 6,16 & 6,16 & 6,16 \\
\hline $0,25 \%$ & & 6,33 & 6,33 & 6,33 & 6,33 & 6,33 \\
\hline $0,5 \%$ & & 6,50 & 6,50 & 6,50 & 6,50 & 6,50 \\
\hline $1 \%$ & & 6,79 & 6,79 & 6,79 & 6,79 & 6,79 \\
\hline
\end{tabular}

Berdasarkan Table 4 di atas hasil pengukuran $\mathrm{pH}$ pada jam ke 72 pada perlakuan kontrol negatif rata-rata $\mathrm{pH}$ mencapai 7 , sedangkan pada perlakuan kontrol positif rata-rata $\mathrm{pH}$ mencapai 6,28 , kemudian untuk konsentrasi $0,125 \%$ rata-rata $\mathrm{pH}$ mencapai 6,16 , pada konsentrasi $0,25 \%$ rata-rata $\mathrm{pH}$ mencapai 6,33 , konsentrasi $0,5 \%$ rata-rata $\mathrm{pH}$ mencapai 6,50 sedangkan untuk konsentrasi $1 \%$ rata-rata $\mathrm{pH}$ mencapai 6,79.

Penghambatan penetasan telur nyamuk DBD (Aedes aegypti) disebabkan oleh senyawa yang berperan sebagai pestisida alami yaitu senyawa flavonoid, tannin, saponin dan terpenoid, senyawa tersebut dapat menghambat pertumbuhan telur menjadi larva, bahkan dapat menyebabkan telur tidak menetas. Hal ini sama dengan penelitian yang telah dilakukan oleh Sho-Xiong Cheah et.al dalam penelitiannya ekstrak dari tumbuhan Artemisia апnиa hasil yang diperoleh yaitu terjadi penghambatan penetasan telur menjadi larva, hal tersebut dikarenakan pada ekstrak tumbuhan tersebut terdapat senyawa yang dapat menghambat penetasan telur yaitu fenolat, terpenoid, alkaloid dan artemesinin (Cheah, Tay, Chan, \& Jaal, 2013b).

Menurut penelitian yang telah dilakukan oleh Nur Vita Purwaningsih et.al menunjukan bahwasanya hasil yang diperoleh dari penelitiannya yaitu ekstrak dari daun 
srikaya (A. squamosa L) dapat menghambat pertumbuhan telur nyamuk DBD (Aedes aegypti) menjadi larva bahkan dapat merusak telur sehingga terjadi kerusakan pada cangkang telur, pada penelitian ini dari kosentrasi $100 \mathrm{ppm}$ sudah dapat menghabat penetasan telur nyamuk DBD (Aedes aegypti) hal tersebut dapat terjadi dikarenakan pada ekstrak daun srikaya ( $A$. squamosa L) mengandung senyawa-senyawa metabolit yaitu flavonoid, alkaloid, triterpenoid, dan saponin.

Senyawa metabolit tersebut masuk dengan cara melalui titik-titik polygonal pada cangkang telur, hal ini terjadi karena adanya zat aktif yang masuk akan menyebabkan ganguan pada metabolisme telur. Pengaruh yang dapat ditimbulkan yaitu dapat menghambat telur menetas menjadi larva (Purwaningsih, Kardiwinata, \& Utami, 2015). Hal ini juga sama dengan penelitian yang telah dilakukan oleh K. Subashini et.al, dengan menggunakan ekstrak daun (Scutellaria violacea) pada penelitiannya menunjukan bahwa senyawa yang berperan sebagai ovisida dapat mengganggu perkembangan embrio dan dapat menyembabkan kematian pada larva (Cheah et al., 2013a).

Telur nyamuk DBD (Aedes aegypti) memiliki lapisan pelindung yaitu korion dimana korion ini berfungsi untuk melindungi embrio dari kondisi eksternal seperti suhu yang tidak mendukung serta zat-zat lain yang yang dapat merusak embrio sehingga menghambat penetasan telur, senyawa aktif dapat masuk dan merusak embrio ini masuk melalui pori-pori korion sehingga embrio rusak dan gagal untuk menetas. Hal ini sama dengan penelitian yang dilakukan oleh peneliti setelah melakukan uji fitokimia terhadap ekstrak daun patikan kebo (Euphorbia hirta L.) hasil yang di peroleh yaitu terdapat senyawa aktif seperti flavonoid, saponin, dan terpenoid, dan tannin. senyawa ini setelah masuk melalui titik-titik polygonal yang terdapat dilapisan luar cangkang telur maka senyawa-senyawa tersebut dapat masuk dan merusak embrio melalui pori-pori korion.

Senyawa yang terdapat pada ekstrak daun patikan kebo (Euphorbia hirta L) seperti senyawa metabolit yang dapat merusak membran sel telur yaitu saponin, hal ini sama dengan penelitian yang dilakukan oleh Intan Mayang sari dengan menggunakan ekstrak bunga krisan (Mayangsari et al., 2015). Sedangkan pada penelitian yang telah dilakukan oleh Agustina Prima Popylaya, et.al, dengan menggunakan ekstrak rimpang lengkuas putih untuk senyawa flavonoid dan terpenoid yang memiliki aktivitas hormon juvenil sehingga dapat mempengaruhi pada perkembangan telur menjadi larva. Selain itu juga terdapat senyawa tanin, senyawa ini dapat menghambat proses pembelahan telur karena senyawa tannin ini akan berikatan dengan yang ada di lapisan telur, sehingga hal tersebut akan menghambat proses pembelahan sel telur (Wirawan, Nurcahyo, \& Prastowo, n.d.).

Selain senyawa metabolit yang dapat menyebabkan telur nyamuk DBD (Aedes aegypti) menetas suhu juga berpengaruh terhadap penetasan telur, suhu normal untuk penetasan telur nyamuk DBD (Aedes aegypti) dari $27^{\circ} \mathrm{C}-32^{\circ} \mathrm{C}$, Telur nyamuk DBD (Aedes aegypti) dalam kondisi normal akan membutuhkan waktu yang cukup cepat untuk menetas yaitu 1-3 hari pada suhu normal $23^{\circ} \mathrm{C}-30^{\circ} \mathrm{C}$ (Yulidar, 2014). Sedangkan dalam penelitian ini suhu selalu mengalami perubahan dari 6 jam pertama sampai 72 jam pengamatan, walaupun suhu dalam keadaan normal tetapi suhu selalu mengalami perubahan.

Hal tersebut dapat mempengaruhi penetasan telur nyamuk DBD (Aedes aegypti), hal ini sesuai dengan penelitian yang telah dilakukan oleh Lars Eiseen, et.al dalam hasil penelitiannya menunjukan bahwasanya perubahan suhu mempengaruhi daya tetas telur nyamuk DBD Aedes aegypti (Eisen et al., 2014). Selain suhu pH juga merupakan salah satu faktor yang mempengaruhi penetasan telur nyamuk DBD (Aedes aegypti), $\mathrm{pH}$ normal untuk penetasan telur nyamuk DBD (Aedes aegypti), yaitu 6-8, jika pH di bawah 6 maka akan 
menghambat penetasan telur nyamuk DBD (Aedes aegypti) bahkan gagal untuk menetas (Arufillah, Ismawati, \& Kharisma, 2016). Pada penelitian ini $\mathrm{pH}$ yang diperoleh normal sehingga $\mathrm{pH}$ tidak berpengaruh atas gagalnya telur nyamuk DBD (Aedes aegypti) untuk menetas. Gagalnya penetasan telur nyamuk DBD (Aedes aegypti) pada penelitian ini dipengaruhi oleh senyawa metabolit yang terdapat pada ekstrak dan keadaan suhu yang tidak stabil.

\section{SIMPULAN DAN SARAN}

Beradaskan hasil dan pembahasan maka dapat disimpulkan Ekstrak daun patikan kebo (Euphorbia hirta L) dapat digunakan sebagai ovisida terhadap telur nyamuk DBD (Aedes aegypti) dari konsentrasi 0,125\% - 1\%. Semakin tinggi konsentrasi ekstrak daun patikan kebo (Euphorbia hirta L) yang digunakan maka semakin banyak telur yang tidak menetas.

Adapun saran dari penelitian yang telah dilakukan yaitu perlu dilakukan adanya pemanfaatan tumbuhan patikan kebo (Euphorbia hirta L) sebagai ovisida terhadap spesies nyamuk lain. Perlu dilakukan penelitian pemanfaatan tumbuhan patikan kebo (Euphorbia hirta L) sebagai insektisida untuk jenis serangga lain.

\section{DAFTAR PUSTAKA}

Arufillah, M. R., Ismawati, I., \& Kharisma, Y. (2016). The influence of PH solution Air Tawas Against Power Tetas Eggs Aedes aegypti.

Cheah, S.-X., Tay, J.-W., Chan, L.-K., \& Jaal, Z. (2013a). Larvicidal, oviposition, and ovicidal effects of Artemisia annua (Asterales: Asteraceae) against Aedes aegypti, Anopheles sinensis, and Culex quinquefasciatus (Diptera: Culicidae). Parasitology Research, 112(9), 3275-3282.

Cheah, S.-X., Tay, J.-W., Chan, L.-K., \& Jaal, Z. (2013b). Larvicidal, oviposition, and ovicidal effects of Artemisia annua (Asterales: Asteraceae) against Aedes aegypti, Anopheles sinensis, and Culex quinquefasciatus (Diptera: Culicidae). Parasitology Research, 112(9), 3275-3282.

Data, P., \& RI, S. E. K. (2010). Buletin Jendela Epidemiologi Demam Berdarah Dengue. Kemenkes RI, Jakarta, 2.

Eisen, L., Monaghan, A. J., Lozano-Fuentes, S., Steinhoff, D. F., Hayden, M. H., \& Bieringer, P. E. (2014). The impact of temperature on the bionomics of Aedes (Stegomyia) aegypti, with special reference to the cool geographic range margins. Journal of Medical Entomology, 51(3), 496-516.

Iftita, F. A. (2016). Uji Efektivitas Rendaman Daun Singkong (Manihot Utilissima) Sebagai Insektisida Terhadap Nyamuk Aedes Aegypti Dengan Metode Elektrik Cair. Jurnal Kesehatan Masyarakat (e-Journal), 4(2), 20-28.

Karim, K., Jura, M. R., \& Sabang, S. M. (2015). Uji Aktivitas Antioksidan Ekstrak Daun Patikan Kebo (Euphorbia hirta L.). Jurnal Akademika Kimia, 4(2), 56-63. 
Mayangsari, I., Sidharti, L., \& Kurniawan, B. (2015). The Effects Of Krisan Flower (Crhysanthemum morifollium) Extract As Ovicide Of Aedes Aegypti's Egg. Jurnal Majority, 4(5).

Mitarlis, M., Ismono, I., \& Tukiran, T. (2011). Pengembangan Metode Sintesis Furfural Berbahan Dasar Campuran Limbah Pertanian Dalam Rangka Mewujudkan Prinsip Green Chemistry (Development Of Synthesis Method Of Furfural From Compost Heap Mixture To Reach Out Green Chemistry Principles). Jurnal Manusia Dan Lingkungan, 18(3), 191-199.

Purwaningsih, N. V., Kardiwinata, M. P., \& Utami, N. W. A. (2015). Daya bunuh ekstrak daun srikaya (A. squamosa L.) terhadap telur dan larva A. aegypti. CAKRA KIMIA (Indonesian E-Journal of Applied Chemistry), 3(3), 96-102.

Raveen, R., Ahmed, F., Pandeeswari, M., Reegan, D., Tennyson, S., Arivoli, S., \& Jayakumar, M. (2017). Laboratory evaluation of a few plant extracts for their ovicidal, larvicidal and pupicidal activity against medically important human dengue, chikungunya and zika virus vector, Aedes aegypti Linnaeus 1762 (Diptera: Culicidae). Int J Mosq Res, 4(4), 17-28.

Wirawan, I. G. K. O., Nurcahyo, W., \& Prastowo, J. (n.d.). Daya Ovicidal Ekstrak Kulit Buah Muda (Calotropis procera) terhadap Haemonchus contortus secara in vitro. Jurnal Sain Veteriner, 33(2).

Yulidar, L. (2014). Figurative Language Used In Owl City's Albums: A Pragmatics Perspective. Universitas Muhammadiyah Surakarta. 